\title{
6. SEDIMENTARY PETROLOGY OF DSDP CORES FROM SITES 362 AND 363, THE WALVIS RIDGE, AND SITE 364, THE ANGOLA BASIN, DRILLED ON LEG 40
}

\author{
Ryo Matsumoto and Minoru Utada, Geological Institute, University of Tokyo, Tokyo, Japan \\ and \\ Hideo Kagami, Ocean Research Institute, University of Tokyo, Tokyo, Japan
}

\begin{abstract}
Sediments in the Angola Basin (Site 364) can be divided into five petrographic units. Units 1 (Cores 1-7) and 2 (Cores 8-21) are deficient in carbonates, with predominant clays while Units 3 (Cores 22-27) and 4 (Cores 28-43) are dominated by calcite interbedded with shales carbon-rich in Unit 4. Unit 5 (Cores 44-46) is characterized by the predominant occurrence of dolomite interbedded with carbon-rich sepropelic shales. Sediments on and near the Walvis Ridge (Sites 362 and 363) are highly calcareous, except for the Pleistocene sediments at Site 362 and some upper Cretaceous mudstones at Site 363. Characteristic differences between the Angola Basin and Walvis Ridge sediments are the occurrences of gypsum and barite in the former and opal in the latter. Relative abundances of clay minerals show marked changes throughout Site 364. Five clay mineral zones are recognized as follows: Zone I (Cores 1-6); mica-kaolinite-smectite-chlorite; Zone II (Cores 7-21); mica-smectite-kaolinite-(chlorite); Zone III (Cores 22-24); smectite-mica; Zone IV (Cores 25-38); mica-smectite(kaolinite); and Zone V (Cores 39-45); kaolinite-mica-chlorite. The boundaries between the clay zones are approximately similar to those of the petrographic units. Some of the mica in Zones IV and V was probably transformed from smectite during diagenesis. Kaolinite-bearing sediments occur chiefly in the Aptian (?) and the Oligocene to Miocene in the Angola Basin and the Walvis Ridge. A common provenance is considered for these sediments, because of their similarity. The upper sapropel in the Coniacian to Albian of Site 364 is chiefly composed of smectite, suggesting that active volcanism occurred somewhere in the proximity in the ocean or on the continent.

Two types of dolomite are recognized on the basis of chemical compositions and occurrences. One is dolostone, which is found exclusively in Unit 5 of the Angola Basin and is characterized by a high content of sodium, averaging $0.1 \mathrm{wt} . \%$ as $\mathrm{Na}_{2} \mathrm{O}$, and a scarcity of iron (type A dolomite). The other is found both in the Angola Basin and Walvis Ridge. It occurs as argillaceous dolomitic limestone and contains abundant iron, averaging $5 \mathrm{~mol} \%$ as $\mathrm{FeCO}_{3}$ (type B dolomite). Type A dolomite is considered to have formed from solutions with high salinity and high $\mathrm{Mg}: \mathrm{Ca}$ ratio, relating to the underlying evaporite formation. Type B dolomite is assumed to have formed in a reducing environment with excess carbonate ions derived from decomposition of the organic materials in the sediments.
\end{abstract}

\section{INTRODUCTION}

Sediments from Sites $362,362 \mathrm{~A}$, and 363 on the Walvis Ridge (Figure 1) and from Site 364 on the continental margin of the Angola Basin (Figure 2) have been studied petrologically. The sediments range in age from the upper Aptian to the Pleistocene. The upper Cretaceous to Recent sediments are principally composed of calcareous ooze, chalk, and limestone. Lower Cretaceous sediments from Site 364 contain significant amounts of dolomite interbedded with sapropelic shales. Site 364 also contains sapropels from the upper Albian to Santonian/Coniacian. Dolostone and dolomitic limestone occur in the upper Aptian and lower Albian.

In this work, bulk samples and clay fractions less than $2 \mu \mathrm{m}$ were analyzed by X-ray diffraction. On the basis of these data the mineralogical composition of sediments of the Angola Basin and Walvis Ridge are compared with each other. In addition dolomite contained in the lower Cretaceous sediments of Sites 363 and 364 was analyzed for $\mathrm{Ca}, \mathrm{Mg}, \mathrm{Fe}, \mathrm{Mn}$, and $\mathrm{Na}$ 

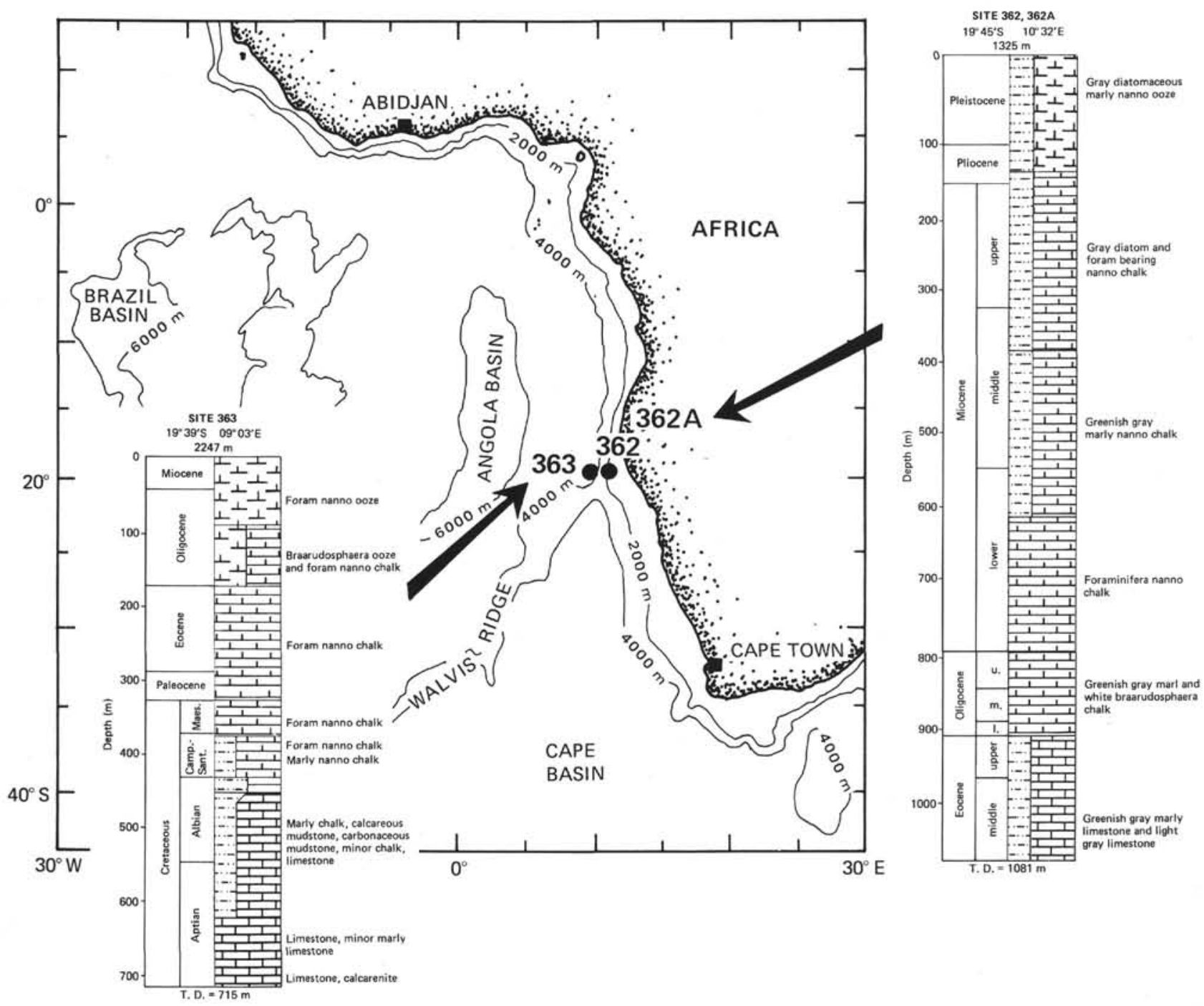

Figure 1. Localities of Sites 362/362A and 363, and the lithology of sediments recovered (after Melguen et al., 1975).

with an electron-probe X-ray microanalyzer. The relation of the chemical composition of dolomite to the depositional environment is discussed.

\section{METHOD OF ANALYSIS}

\section{X-Ray Diffraction Analysis}

Thirty-four samples from Sites 362 and $362 \mathrm{~A}, 37$ samples from Site 363, and 206 samples from Site 364 were analyzed. All the samples selected were crushed and ground in alumina-porcelain containers with a motor-driven vibration mill. Powder samples were pressed into an aluminum holder. The relative abundances and percentages of the constituent minerals excepting clay minerals were determined from calibration curves based on the height of the most intense X-ray peak of each mineral as follows: calcite: $3.035 \AA$, dolomite $2.886 \AA$, quartz $3.343 \AA$, K-feldspar $3.24 \AA$, plagioclase $3.18 \AA$, pyrite $1.63 \AA$, clinoptilolite $9.00 \AA$, gypsum $2.87 \AA$, and opal $4.05 \AA$. Opal is of very low crystallinity, only showing a low intensity reflection around $4.05 \AA$.

For clay mineral analysis, preferred orientation slides were made from clay fractions less than $2 \mu \mathrm{m}$. Clay minerals were identified by diagnostic changes of X-ray diffractometer pattern on treatment with ethylene glycol and hydrazine hydrate. The characteristic property of the smectite group is the shifting of the basal spacing of $17 \AA$ upon treatment with etylene glycol. The $7 \AA$ peak of the kaolinite is apt to be confused with that of chlorite. But kaolinite can be differentiated from chlorite by the shift of the peak to $10 \AA$ after treatment with $\cdots$ drazine hydrate for $1 \mathrm{hr}$ (Wada and Yamada, 1968) (Figure 3). The basal spacing of the $7 \AA$ septechlorite group unfortunately shifts to $10 \AA$ on treatment with hydrazine, therefore, it should be noted that "kaolinite" in this paper may include those $7 \AA$ clay minerals. Moreover, the determination of the constituents of mixed-layer clay minerals is ambiguous. Clay minerals detected include kaolinite, mica (illite), chlorite, and smectite (montmorillonite). The relative abundances of each mineral in the less than $2 \mu \mathrm{m}$ fraction were expressed as the values of corrected peak intensities, which were obtained by multiplying the measured intensities by 1.7 for mica, 1.5 for chlorite, and 1.0 for kaolinite and smectite, according to Oinuma and Kobayashi (1961b). The percentage of abundance of each mineral in a four- 

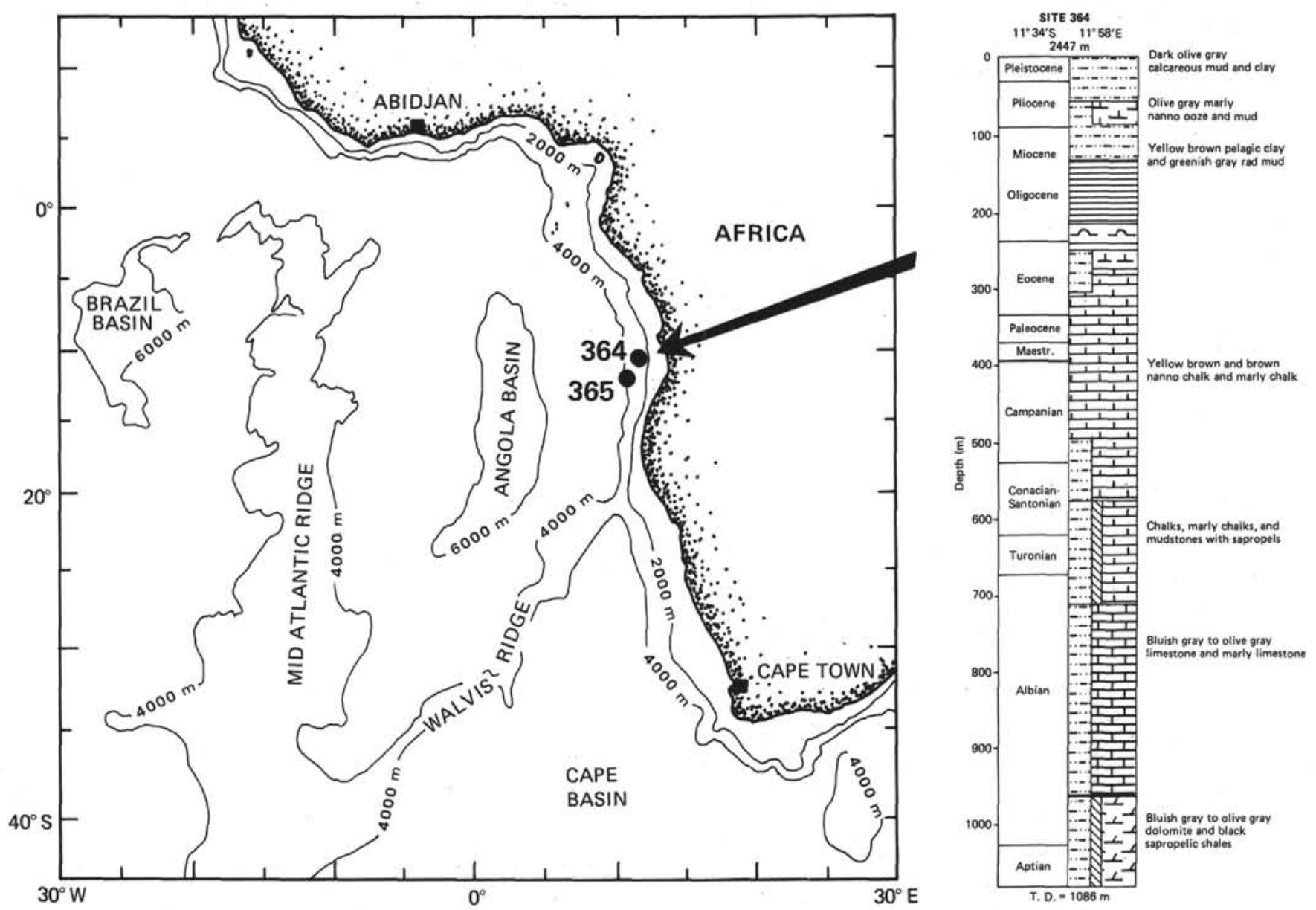

Figure 2. Locality of Site 364 and the lithology of the sediments recovered (after Melguen et al., 1975).

component clay system (kaolinite, mica, chlorite, and smectite) was calculated from the corrected intensities of the minerals.

$\mathrm{X}$-ray diffractometer patterns of all samples were made with nickel-filtered $\mathrm{Cu}-\mathrm{K} \alpha$ radiation at a scanning speed of $2^{\circ} 2 \theta / \mathrm{min}$ on a Phillips Norelco Diffractometer. Instrument settings were: $35 \mathrm{kv} / 15$ $\mathrm{mA}$, time constant 5 , slit $1^{\circ} / 0.006$ in. $/ 1^{\circ}$, attenuation 2 , scintillation counter base $4.10 \mathrm{~V} /$ window $2.00 \mathrm{~V}$. This gives peak intensities of $90-93$ thousand $\mathrm{cps}$ at the $26.6^{\circ}$ quartz peak.

\section{X-Ray Microprobe Analysis}

Quantitative chemical analysis of dolomite was obtained with an electron probe X-ray microanalyzer of the Japan Electron Optics Laboratory Co., Ltd., Model JXA-5 with $40^{\circ}$ take off angle. The following minerals were used as the standard materials: $\mathrm{Mg}$ : Dolomite of Kasuga Mine, Japan, Ca: Iceland spar, Iceland, Fe: Siderite of Ivigtut, Greenland, Mn: Rhodochrocite of Takatori Mine, Japan, Na: Albite of Amelia, U.S.A. The applied accelerating voltage was 15 $\mathrm{kv}$ and the electron beam diameter was $2-3 \mu \mathrm{m}$ on the specimen. The specimen current was 0.01 to $0.02 \mu \mathrm{amp}$ measured on periclase. Corrections for absorption, fluorescence, ionization, and backscattering effects of each element were collectively made by the method of Bence and Albee (1968), and Albee and Ray (1970).

\section{BULK MINERALOGY}

\section{Angola Basin}

Site 364 is dominated by calcite, but the calcite is diluted by abundant terrigenous materials in the upper Cores (1-7) and the middle cores (22-27) of this site. In the lower cores (44-46), calcite disappears and dolomite increases (Figure 4).

This site has been divided into five petrographic units as follows: Unit 1: Cores 1 to 7 (Pleistocene to Eocene); Unit 2: Cores 8 to 21 (Eocene to upper Cretaceous); Unit 3: Cores 22 to 27 (upper Cretaceous); Unit 4: Cores 28 to 43 (lower Cretaceous); Unit 5: Cores 44 to 46 (lower Cretaceous). Unit 1 is characterized by a scarcity of calcite and an abundance of terrigenous quartz, plagioclase, $\mathrm{K}$-feldspar, and clay minerals. Cores 6 and 7, especially, lack calcite and dolomite. These cores and Core 8 in Unit 2 contain significant amounts of clinoptilolite. Unit 2 is dominated by calcite, averaging 75 wt \%, except for Core 12 . Some sections of Core 12 are exceptionally low in calcite and high in terrigenous materials. A small amount of dolomite occurs in the cores of the lower part of this unit. Pyrite and clinoptilolite occur, though sporadically and in minor amounts. In the carbonaceous shales of Cores 22 to 24 of Unit 3, calcite suddenly decreases and dolomite disappears, while terrigenous materials increase correspondingly. Barite 

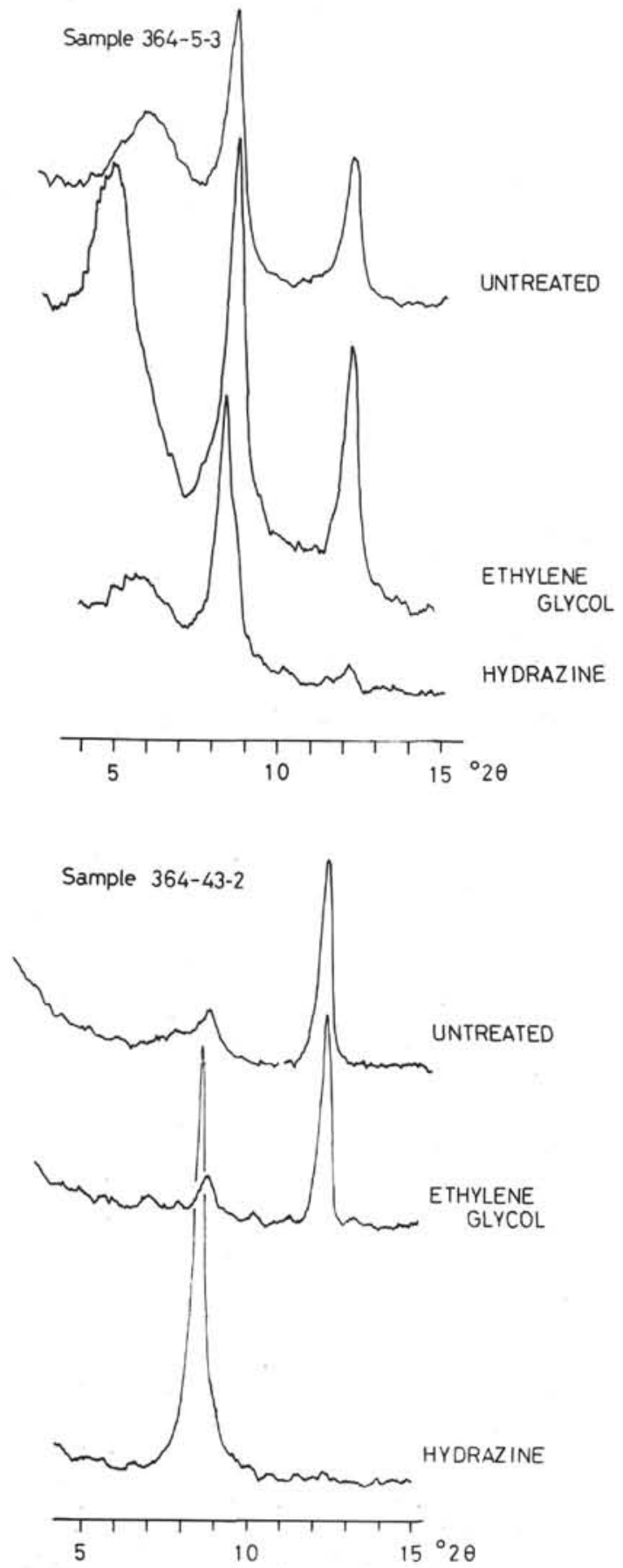

Figure 3. X-ray powder diffractogram of clay from Section 5-3 and Section 43-2 of Site 364. Section 364-5-3 consists of mica, kaolinite, smectite, and chlorite; Section 364 43-2 consists of kaolinite and mica.

occurs in the form of sparry coarse grains in calcareous mud of Sample 22, CC and Section 23-2 (Plate 1, Figure 3). In Cores 25 to 27 , calcite increases up to $50 \mathrm{wt} \%$, but contents of terrigenous materials also remain high. Pyrite is rather rare, considering that this unit includes abundant carbonaceous materials which indicate that intense reducing condition prevailed during their deposition. In Unit 4 , calcite is again dominant, averaging $65 \mathrm{wt} \%$, however the terrigenous component is larger than in Unit 2. Dolomite was detected in almost all cores and varies up to 44 wt \% in Section 385. The lower part of this unit, from Core 39 to 43 , consists of sapropelic shale and shows a gradual decrease in calcite, while the terrigenous suite and pyrite become dominant. These cores are the most pyritic of Site 364 sediments. This together with the abundant organic carbon indicate that an early period of reducing conditions prevailed during their deposition. Section 39-5 contains a great amount of barite as similarly observed in Core 23 . Unit 5 , the lowermost part of the hole, is predominantly dolomite. Calcite is not detected, but gypsum is characteristic to this unit. Pyrite occurs in all cores of this unit, although in a smaller amount compared with Unit 4.

\section{Walvis Ridge}

Sites 362 and $362 \mathrm{~A}$ on the Walvis Ridge consist of calcareous sediments containing more than $60 \mathrm{wt} \%$ calcite, except for Pleistocene sediments (Figure 5). In Cores 2 to 9 , calcite is rather rare and terrigenous quartz is more abundant than in deeper cores. In these shallower cores, a small amount of pyrite commonly occurs. Calcite increases downwards and amounts up to $60 \mathrm{wt} \%$ in Core 11 with a corresponding decrease of terrigenous quartz. No significant changes in the contents of calcite and terrigenous materials occur throughout the sediments from Pliocene (Core 11) to Eocene (Site 362A, Core 12). Opal occurs in the diatom-bearing nanno chalk of Cores 18, 19, and 26.

Site 363 is also dominated by carbonate minerals, chiefly calcite (Figure 6). According to the carbonate mineral composition, this site can be divided into mineralogic zones as follows: Zone I: Cores 1-24 (Tertiary and upper Cretaceous) and Zone II: Cores 26-40 (mainly lower Cretaceous). Calcite is overwhelmingly predominant throughout Zone I. Pyrite, zeolite (mainly clinoptilolite), and opal are very rare in these cores. Zone II is characterized by the occurrence of dolomite. Pyrite, zeolite (mainly clinoptilolite), and opal are rather common in this zone. Terrigenous quartz suddenly increases in Core 26 corresponding to the occurrence of pyrite-rich shale and gradually decreases downwards. Dolomite increases in Cores 32 to 39 , but it is not observed in calcarenite in the bottom of Core 40. Significant amounts of opal occur in Cores 30 to 40. This may suggest that silica-secreting organisms were present and their productivity was too high to have been diluted by the terrigenous influx and high productivity of carbonates.

\section{Comparison Between Angola Basin and Walvis Ridge}

Generally, calcite is the most abundant mineral throughout the sediments cored in the Angola Basin and on Walvis Ridge, but the Walvis Ridge sediments contain more calcite and less terrigenous material. PlioPleistocene sediments of Sites 362 and 364 are poor in carbonate and characterized by the abundance of terrigenous materials. Eocene and Miocene sediments in the Angola Basin are also poor in carbonates, while those on the Walvis Ridge are dominated by calcite. Eocene to Miocene carbonate sediments on the Walvis 


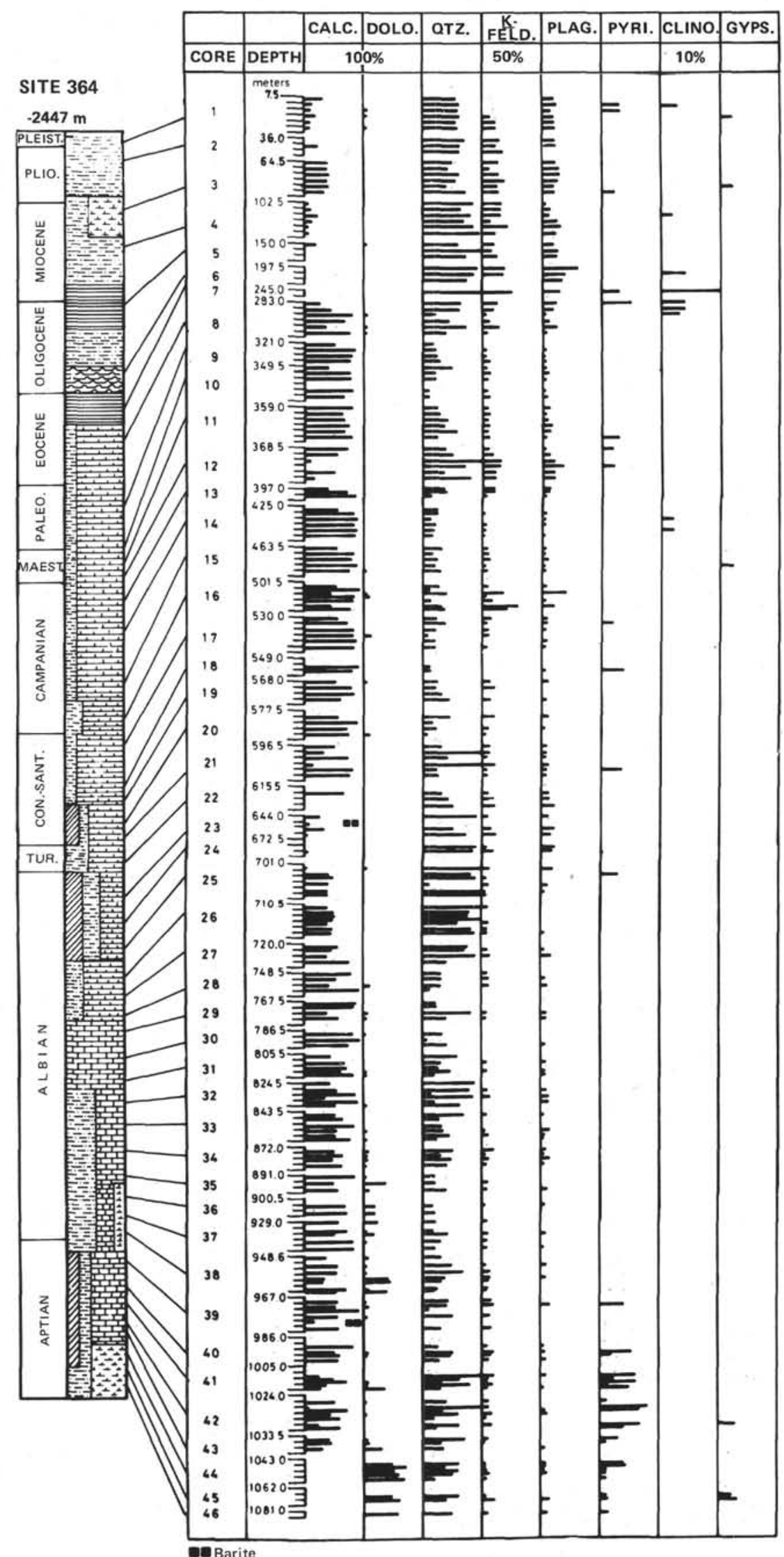

Figure 4. Mineral composition of bulk sample of Site 364. 

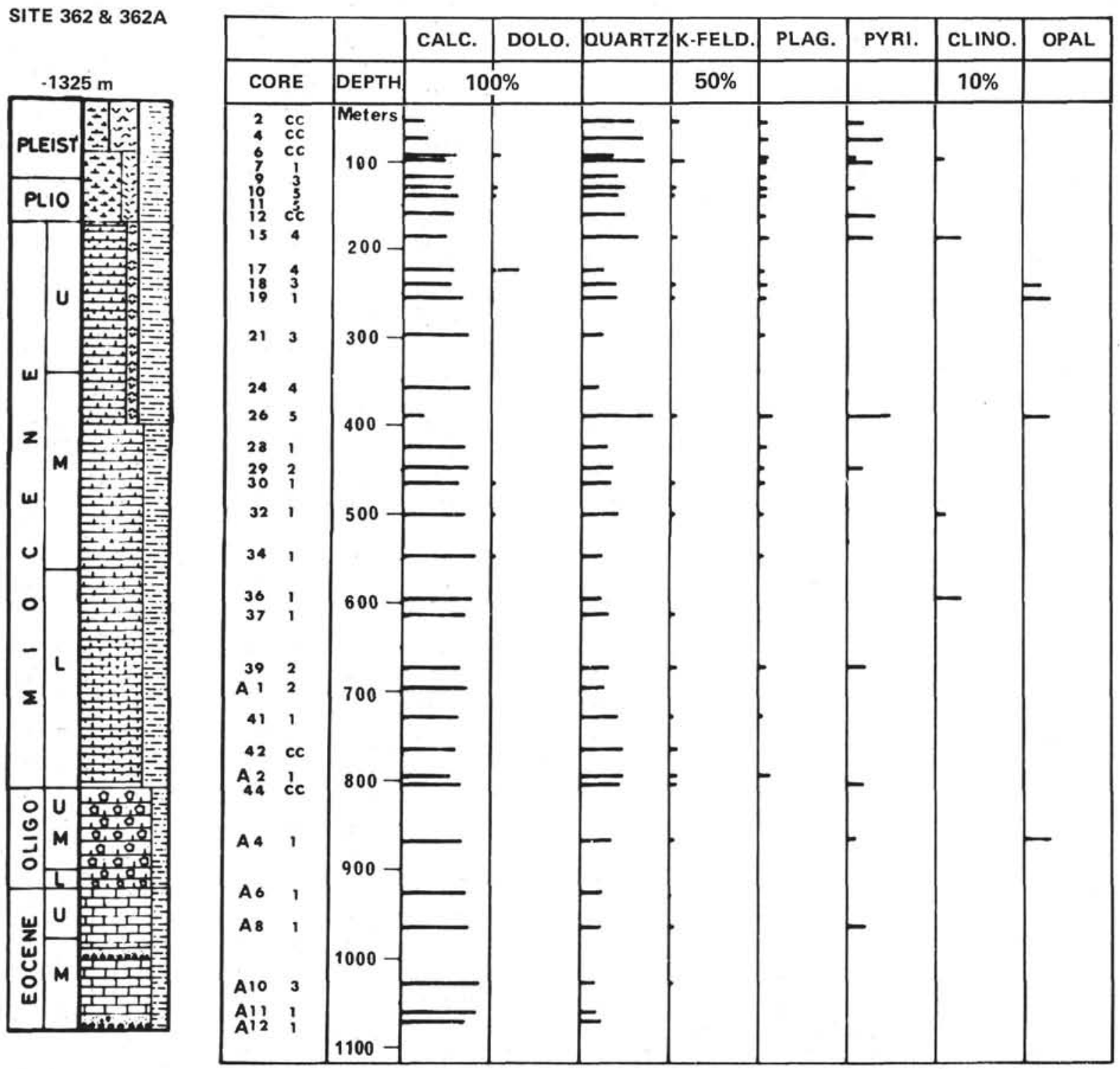

Figure 5a. Mineral composition of bulk samples of Holes 362/362A.

Ridge are thicker than clays of similar age in the Angola Basin. The difference was caused by the dilution of terrigenous material with high rates of production and deposition of carbonates on the Walvis Ridge. Unit 3 (upper Cretaceous) of Site 364 in the Angola Basin is relatively poor in carbonates, with a corresponding increase in the terrigenous suite. An increase of terrigenous material in sediments of this age was also noted at Site $362 / 362 \mathrm{~A}$, but it is not as marked as at Site 364 . The contents of terrigenous minerals increase again in the lower Cores (41-46) of Site 364, however the contemporaneous sediments on the Walvis Ridge are poor in terrigenous materials and are chiefly composed of limestone with calcarenite. Dolomite occurs in the lower Cretaceous sediments of Site 363. The Aptian (?) dolomite in the Angola Basin occurs as dolostone without calcite. The dolomite is sometimes accompanied by gypsum. Pyritic sediments, which indicate reducing conditions, occur together with sapropelic layers. Clinoptilolite occurs especially in
Cores 7 and 8 in the Angola Basin but is restricted mainly to the lower Cretaceous at Site 363 on the Walvis Ridge. Opal is characteristic of the Walvis Ridge sediments; barite and gypsum are, on the contrary, exclusive to the Angola Basin. The occurrence of gypsum in Unit 5 of Site 364 suggests that hypersaline conditions penetrated into the unit, judging from acoustic data which show the presence of evaporite formations below this site, and the presence of high salinity pore waters in the lowermost sediments.

\section{CLAY MINERALOGY}

Sediments at Site 364 can be divided into five clay mineral zones according to the relative abundances of clay minerals as shown in Figure 6 and as follows: Zone I: Cores 1-6 Pleistocene-Oligocene, mica-kaolinitesmectite-chlorite; Zone II: Cores 7-21 EoceneConiacian (?), mica-smectite-kaolinite-(chlorite); Zone III: Cores 22-24 Santonian-Albian (?), smectite-mica; Zone IV: Cores 25-38 Albian, mica-smectite-kaolinite; 


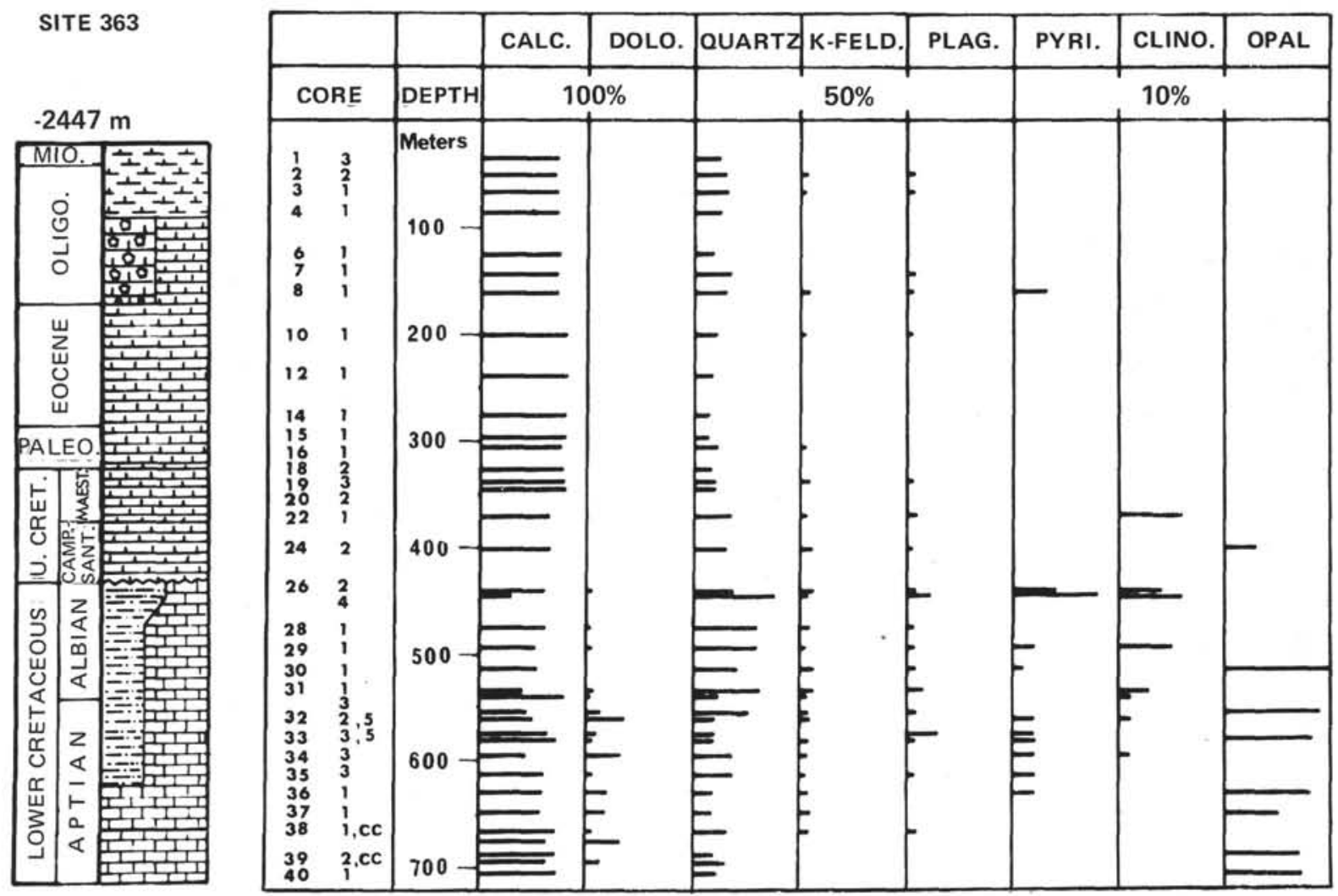

Figure 5b. Mineral composition of bulk samples of Site 363.

Zone V: Cores 39-45 lower Albian-Aptian (?), kaolinite-mica-chlorite.

Zone I is rich in clay minerals; it is characterized by significant amounts of mica, kaolinite, and smectite. Small amounts of chlorite also occur in most samples. The dominant occurrence of kaolinite probably reflects intense weathering on the African continent. The contents of clay minerals decreases in Zone II. They consist principally of mica and smectite with sporadic occurrences of kaolinite and chlorite. Zone II, which represents carbonate-free sediments, is rich in clay minerals, especially smectite. The predominant occurrence of smectite in Cores 22 to 24 may reflect a change of provenance or active volcanism somewhere nearby in the ocean or on the continent. Zone IV is again scarce in clay minerals, which are principally composed of mica and smectite. Zone V is characterized by the occurrence of kaolinite and chlorite, and the absence of smectite.

The relative percentage of smectite in clay minerals gradually decreases downward from Zone III to Zone IV and becomes negligible in Zone V, whereas mica gradually increases downward. It is noteworthy that montmorillonite-illite mixed-layer clay $(11-12 \AA$ basal spacing) is often observed in Zones IV and V. These occurrences suggest that diagenetic changes of smectite may cause a relative increase of mica with respect to mixed layer minerals. On the Walvis Ridge (Site 362), Oligocene and younger sediments contain smectite, mica, kaolinite, and chlorite as in sediments of Site 364 (Figure 7). Eocene, Upper Cretaceous, and Albian sediments (Site 363, Cores 12-33) are characterized by a combination of mica and smectite. This also corresponds to sediments at Site 364 . Cores 35 to 39 of Site 363 (Albian to Aptian [?]) consist of smectite, mica, and kaolinite. However chlorite, which is observed in the Aptian (?) sediments of Site 364, does not occur in these cores. It is evident that kaolinite occurs in almost the same stratigraphic horizons in the Angola Basin and Walvis Ridge. It is noteworthy that significant amounts of kaolinite occur in the Aptian (?) sediments of both sites, notwithstanding the differences in the depth of burial and depositional environment between them. The depth of burial of the Aptian sediments of the Walvis Ridge is 715 meters, while that of the Angola Basin amounts to 1086 meters. The Angola Basin had reducing conditions at this time, as indicated by the sapropelic shales while the Walvis Ridge was oxidizing. By this evidence, it appears, then, that kaolinite in the Aptian (?) sediments is detrital rather than authigenic.

\section{CHEMICAL COMPOSITION OF DOLOMITE}

\section{Dolomite at Site 364}

Dolomite occurs chiefly in Units 4 and 5 (lower Cretaceous) as shown in Figure 4. It increases significantly in Unit 5 . Unit 4 dolomite occurs with calcite, while Unit 5 dolomite does not. The dolomite is commonly rhombohedral, but the sizes are different in the two units. Unit 4 dolomite ranges mostly from $18 \mu \mathrm{m}$ to $96 \mu \mathrm{m}$, while Unit 5 dolomite ranges from 15 $\mu \mathrm{m}$ to $30 \mu \mathrm{m}$ (Plate 1, Figures 1 and 2). The $d_{104}$ spacing of dolomite varies from $2.888 \AA$ to $2.908 \AA$ (Figure 8 ). 

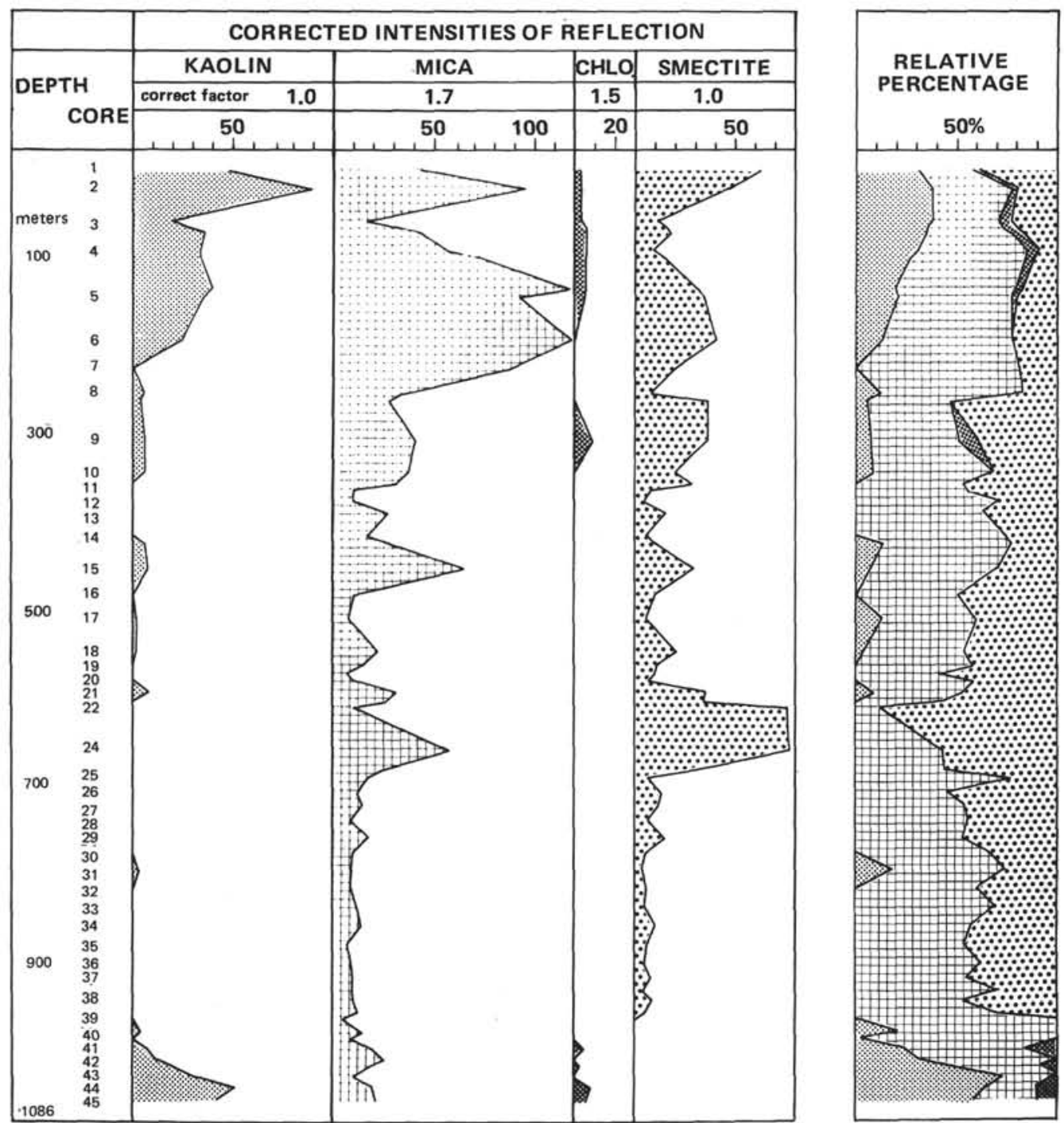

Figure 6. Clay mineral composition of clay fractions $(<2 \mu \mathrm{m})$ of Site 364.

Differences in chemical composition of dolomite were determined by X-ray microanalyzer. Unit 4 dolomite is relatively rich in iron $(0.5$ to $10.0 \mathrm{~mol} \%$ as $\left.\mathrm{FeCO}_{3}\right)$ and is called high iron dolomite, while Unit 5 dolomite contains less iron, $\left(<0.3 \mathrm{~mol} \%\right.$ as $\left.\mathrm{FeCO}_{3}\right)$ and is called low-iron dolomite. The high-iron dolomite in Unit 4 represents a wide compositional variation in the $\mathrm{CaCO}_{3}-\mathrm{MgCO}_{3}-\mathrm{FeCO}_{3}$ series (Figure 10). The contents of $\mathrm{CaCO}_{3}$ range from 54.4 to $59.7 \mathrm{~mol} \%, \mathrm{MgCO}_{3}$ from 32.3 to $42.5 \mathrm{~mol} \%$ and $\mathrm{FeCO}_{3}$ from 0.2 and $10.0 \mathrm{~mol} \%$, except for one analysis showing $0.03 \mathrm{~mol} \%$ as $\mathrm{FeCO}_{3}$. The content of $\mathrm{MnCO}_{3}$ varies widely from 0.04 to 0.64 $\mathrm{mol} \%$ and does not show any significant correlation to the content of $\mathrm{FeCO}_{3}$. High-iron dolomite crystals commonly have a compositional zoning chiefly in the $\mathrm{FeCO}_{3}-\mathrm{MgCO}_{3}$ series. Within individual crystals $\mathrm{MgCO}_{3}$ is high in the core and decreases outwards, while $\mathrm{FeCO}_{3}$ increases outwards. Sometimes however, the $\mathrm{MgCO}_{3}$ is slightly higher and $\mathrm{FeCO}_{3}$ is lower at the crystal rims (Figure 11). Some iron-rich rims of the zoned crystals have the chemical composition of calcian ankerite, as defined by Deer et al. (1963). High-iron dolomite rarely includes calcite as shown in Figure 11.
Low-iron dolomite in Unit 5 shows significant compositional variations in the $\mathrm{CaCO}_{3}-\mathrm{MgCO}_{3}$ series. The content of $\mathrm{CaCO}_{3}$ ranges from 51.5 to $56.2 \mathrm{~mol} \%$, while the $\mathrm{MgCO}_{3}$ ranges from 43.5 to $48.1 \mathrm{~mol} \%$. The $\mathrm{FeCO}_{3}$ ranges from negligible to $0.3 \mathrm{~mol} \%$ and the $\mathrm{MnCO}_{3}$ ranges from 0.1 to $0.3 \mathrm{~mol} \%$. No significant correlation occurs between $\mathrm{FeCO}_{3}$ and $\mathrm{MnCO}_{3}$. Careful analysis by the step-counting method with the $\mathrm{X}$-ray microanalyzer reveals that the dolomite in Section $46-1$ has $0.1 \mathrm{wt} \% \mathrm{Na}_{2} \mathrm{O}$. Compositional zoning was found in a dolomite crystal in the Section 45-3; within the crystal the core is low in excess $\mathrm{CaCO}_{3}$ while the rim is high in $\mathrm{CaCO}_{3}$ and low in $\mathrm{MgCO}_{3}$. A dolomite crystal including pyrite was observed in the Section 45-3. The pyrite is irregularly shaped and about $7 \mu \mathrm{m}$ across. This phenomenon clearly suggests that the pyrite was formed prior to the formation of dolomite.

\section{Dolomite at Site 363}

Dolomitic sediments were found chiefly in Zone II, except for calcarenite of Core 40 (Figure 9). The dolomite is always associated with calcite. Crystals are commonly rhombohedral and range mostly from 16 to 
SITE $362 \& 362 A$

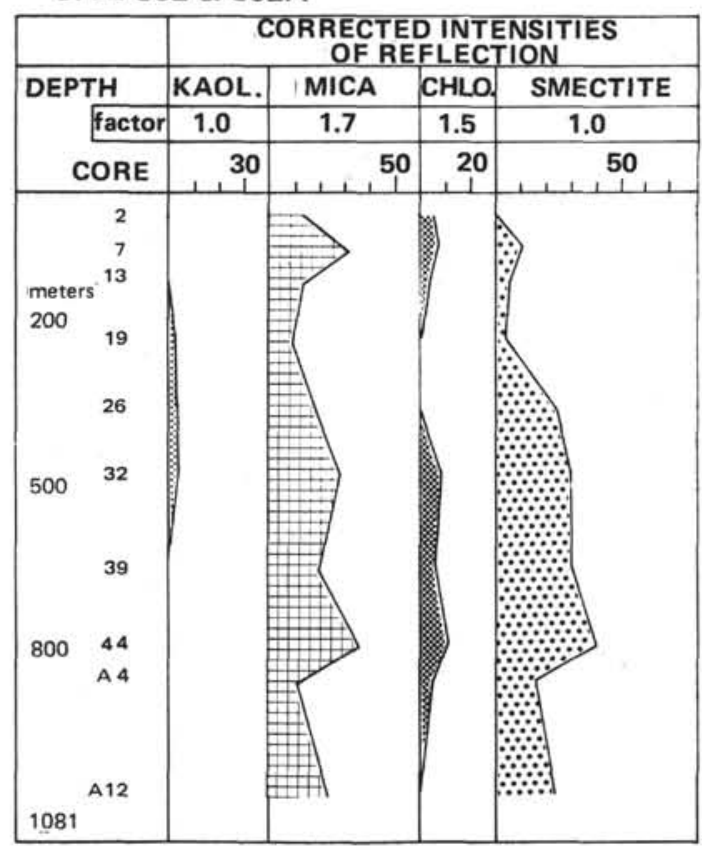

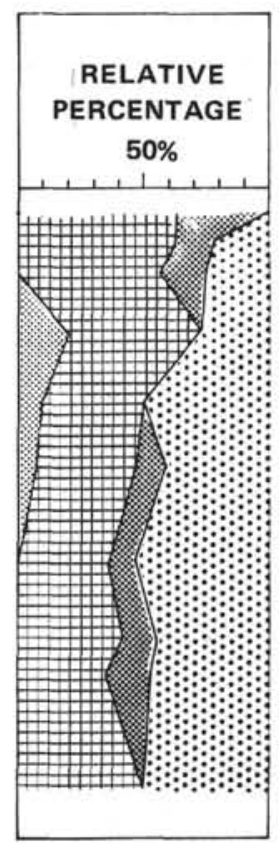

SITE 363
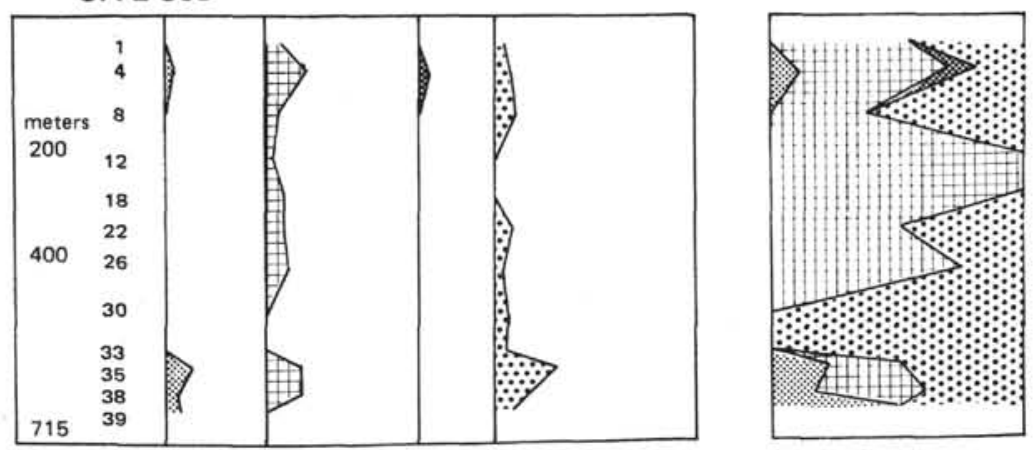

Figure 7. Clay mineral composition of clay fractions $(<2 \mu \mathrm{m})$ of Site $362 / 362 A$ (above) and of Site 363 (below).

$80 \mathrm{~m}$. The $d_{104}$ spacings of Zone II dolomite were 2.904 to $2.909 \AA$, suggesting variations in the chemical composition. Dolomite at Site 363 represents wide compositional variation in the $\mathrm{CaCO}_{3}-\mathrm{MgCO}_{3} \mathrm{FeCO}_{3}$ series (Figure 12) as observed in Unit 4 dolomite at Site 364. The content of $\mathrm{CaCO}_{3}$ ranges from 54.0 to 58.1 $\mathrm{mol} \%$, the $\mathrm{MgCO}_{3}$ from 34.6 to $44.1 \mathrm{~mol} \%$, and the $\mathrm{FeCO}_{3}$ from 0.3 to $11.2 \mathrm{~mol} \%$. Calcian ankerite is detected in this site, as in Unit 4 of Site 364. The content of $\mathrm{MnCO}_{3}$ ranges from negligible to $0.6 \mathrm{~mol} \%$, although it is not related to the content of $\mathrm{FeCO}_{3}$. The content of sodium is mostly less than 0.05 wt\% Naz?. Compositional zoning in single crystals occurs, as in the high-iron dolomite crystals of Site 364. Within the crystals, the cores are high in $\mathrm{MgCO}_{3}$ and low in $\mathrm{FeCO}_{3}$, while the rim is low in $\mathrm{MgCO}_{3}$ and high in $\mathrm{FeCO}_{3}$. The content of $\mathrm{CaCO}_{3}$ decreases at the rim of the crystals in two samples, but in one sample it increases outwards.

\section{Summary}

The high iron dolomites of Sites 364 and 363 do not show (015) reflection, suggesting that they are poorly ordered and best termed protodolomite. The low iron dolomite of Site 364 shows a weak (015) reflection, suggesting a development of superlattice structure (Goldsmith and Graf, 1958a, b).

The chemical composition of dolomite has often been calculated by measuring the peak displacement and relating the shift in lattice spacing to compositional variation in the $\mathrm{CaCO}_{3}-\mathrm{MgCO}_{3}$ series. But this method is not suitable for iron-rich dolomite, as shown in Table 2 and Figure 13. The ranges of $d_{104}$ spacing calculated from the chemical compositions and those measured by $\mathrm{X}$-ray diffraction analysis are represented in Table 2. They show rather good correlation. The chemical compositions calculated from the peak displacements are also shown in this table.

Two types of dolomite were distinguished according to their chemical compositions, especially the iron contents, as shown in Table 3. Type A dolomite is always poor in iron, and relatively rich in sodium. It occurs as olive-gray argillaceous dolostone with associated organic materials and pyrite. It also contains a small amount of gypsum. Type B dolomite is rich in iron and occurs as dark gray dolomitic limestone. It is 


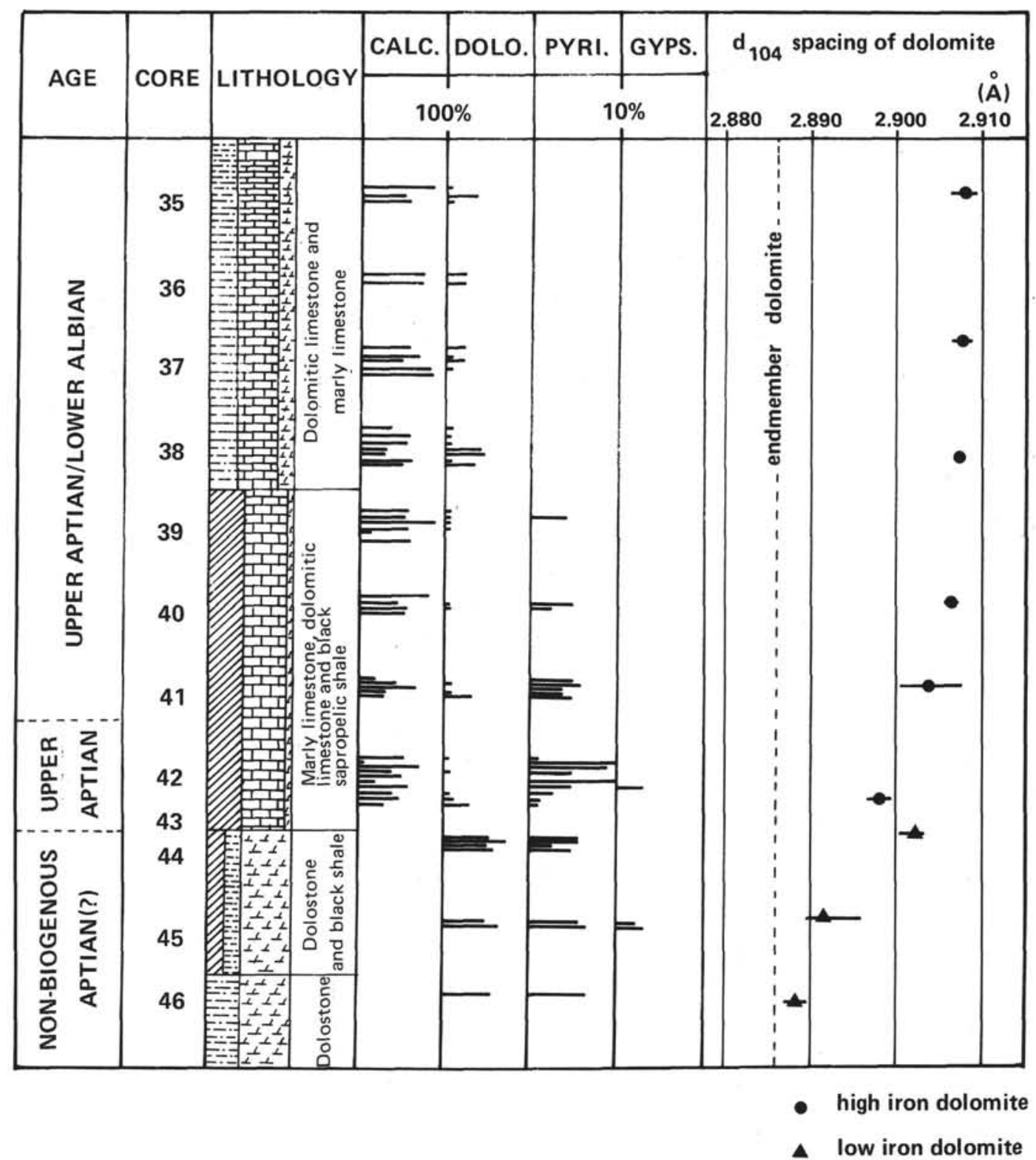

Figure 8. The $d_{104}$ value of dolomite and lithology of associated sediments of Site 364.

often associated with organic materials and pyrite, but also occurs in slightly oxidizing sediments at Site 363 .

\section{ORIGIN OF LOWER CRETACEOUS DOLOMITE IN ANGOLA BASIN AND WALVIS RIDGE}

\section{Type A Dolomite}

Type A low-iron dolomite contains a relatively high content of sodium. The bulk sodium content of dolomite is believed to be a useful indicator of the salinity of dolomitizing brines (Fritz and Katz, 1972; Land and Hoops, 1973). Moreover, a small amount of gypsum was recognized in Core 45 . The acoustic data and high interstitial water salinities suggest the existence of evaporitic deposits a few tens of meters below the dolostone bed. These evidences strongly suggest that the low-iron dolomite of Site 364 formed in a solution with high salinity and high $\mathrm{Mg}: \mathrm{Ca}$ ratio, probably relating to the Aptian evaporite formation. Within the initial opening of the Atlantic Ocean, the evaporites were deposited from seawater with a high salinity, resulting in an increase in the ratio of $\mathrm{Mg}: \mathrm{Ca}$ in seawater. Euxinic conditions then ensued with deposition of sapropelic shales and carbonates. Dolomite and calcian dolomite were probably formed from high $\mathrm{Na}$, high $\mathrm{Mg}$ :Ca pore water replacing calcite during diagenesis. Alternating, the dolomite may have formed directly from the still high- $\mathrm{Na}$ high- $\mathrm{Mg}$ bottom waters prevailing just after cessation of evaporite conditions. Low-iron dolomite is not associated with calcite at all, probably due to intense dolomitization. In the dolomites, excess $\mathrm{CaCO}_{3}$ gradually increases upwards in Unit 5 of Site 364. This correlates with a decline in salinity, and $\mathrm{Mg}: \mathrm{Ca}$ ratio in pore waters upwards, but may also represent a temporal decline in the salinity and $\mathrm{Mg}$ :Ca ratio of the bottom waters from 


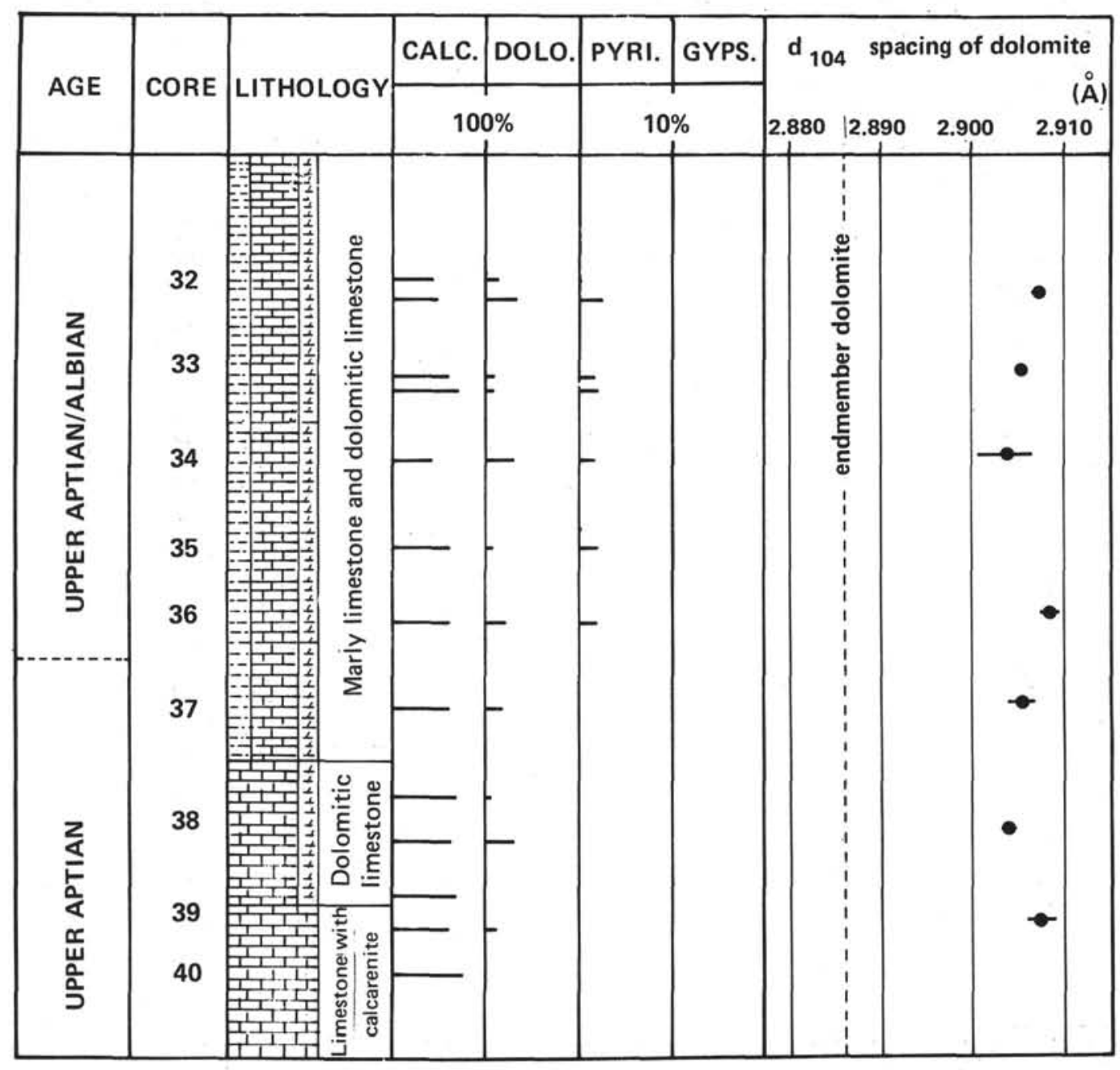

- high iron dolomite

Figure 9. The $d_{104}$ value of dolomite and lithology of associated sediments of Site 363.

which the dolomites may have been deposited. The zoned dolomite crystals with high-Ca rims in Core 44 suggest that decreases of salinity and $\mathrm{Mg}: \mathrm{Ca}$ ratio occurred in the latter stages of dolomitization.

\section{Type B Dolomite}

Since it is believed that iron carbonate is easy to precipitate in euxinic conditions, it seems reasonable that iron-rich dolomite including ankerite was formed in the sapropelic shales with abundant pyrite at Site 364. Since dolomitization occurs in solutions with a high $\mathrm{Mg}: \mathrm{Ca}$ ratio, an increase of $\mathrm{Fe}^{+2}$ may similarly have produced iron-rich dolomite. It is plausible that type B dolomite was formed in euxinic sediments with interstitial solutions having abundant $\mathrm{Fe}^{+2}$. There are two possible reasons why $\mathrm{Fe}^{+2}$ was fixed as carbonate rather than sulfide: the sedimentary basin was not so intensely reducing that iron carbonate was stable relative to iron sulfide (Krumbine and Garrels, 1952) or the activity of carbonate ions was relatively high compared with sulfide ions. This may partly have resulted from the decomposition of abundant organisms in the sapropelic shales or may be due to a rapid rate of accumulation of lower Cretaceous sediments. The decomposition of abundant organisms generates a high concentration of carbonate ions (Matsumoto and Iijima, 1975), and a rapid rate of accumulation is apt to weaken the activity of sulfurreducing bacteria (Taylor and Spears, 1967) and to prevent sulfate ions from diffusing into sediments from seawater (Raiswell, 1971). The reason why siderite was not precipitated can be explained by the abundance of magnesium ions contained originally in seawater and derived from high magnesian calcite of calcareous fossils.

The origin of high-iron dolomite in oxidizing sediments of Cores 37 to 39 at Site 363 cannot be explained by an increase of $\mathrm{Fe}^{+2}$ under low $\mathrm{Eh}$ condition. It may reflect an increase of total iron in sediments, but this was not confirmed by bulk chemical analyses. It may also reflect the passage of $\mathrm{Fe}^{+2}$ and $\mathrm{Mg}^{+2}$-rich solutions from underlying basalts into the overlying sediments (Perry et al., 1976). These cores are inferred to be only tens of meters above volcanic basement at Site 363 .

Coexistence of dolomite and euxinic sediments has been demonstrated at many DSDP sites. At site 147 in the Cariaco Basin, dolomite occurs Pleistocene 


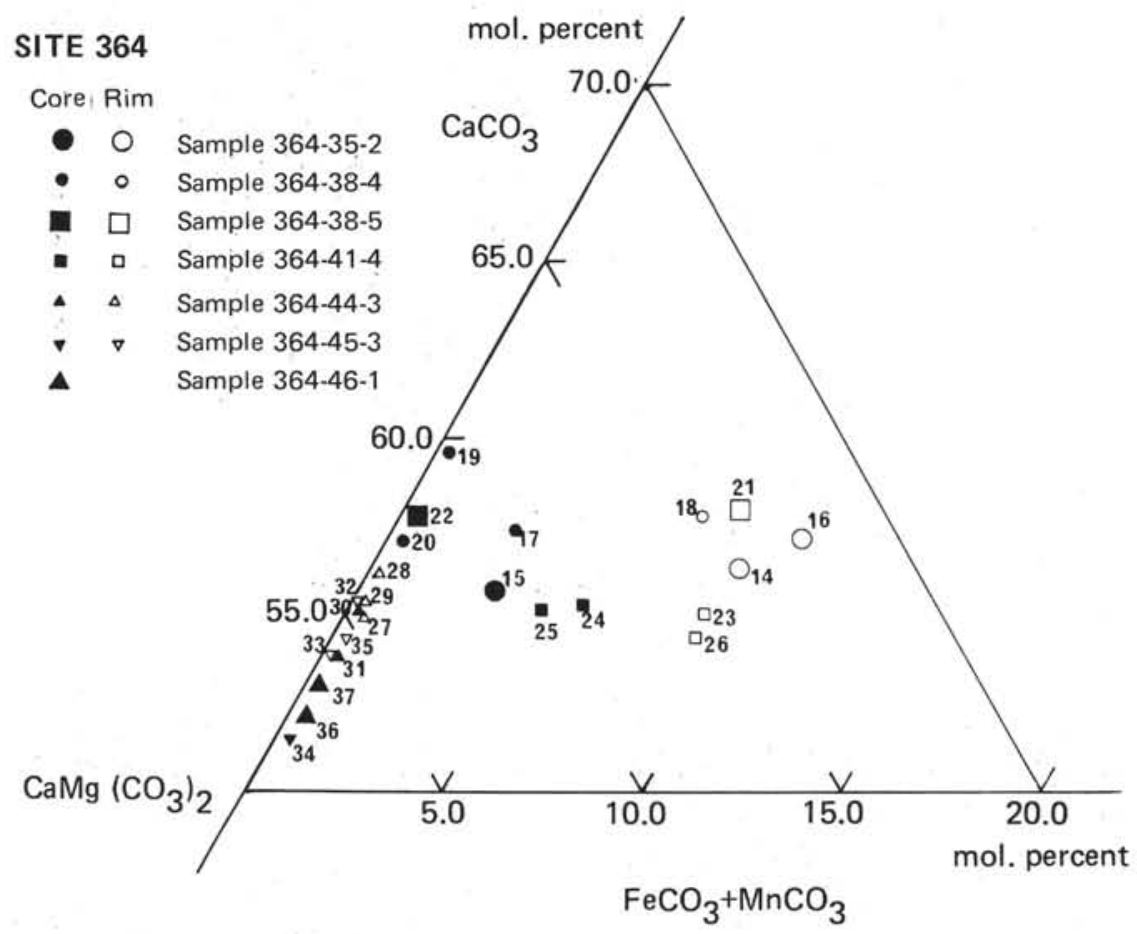

Figure 10. Chemical composition of dolomite at Site 364 plotted in the system $\mathrm{CaCO}_{3}-\mathrm{MgCO}_{3}-\mathrm{FeCO}_{3}+\mathrm{MnCO}_{3}$.

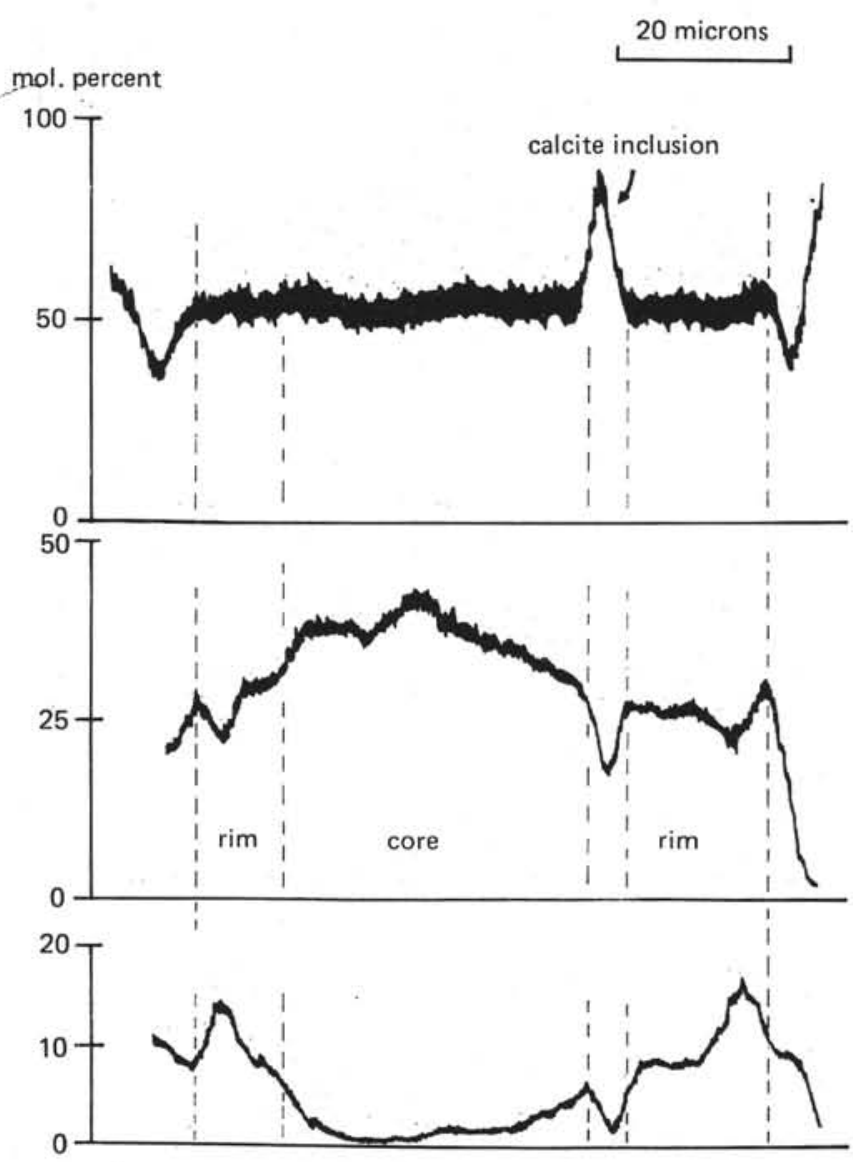

Figure 11. Beam scanning profiles by $\mathrm{CaK} \alpha, \mathrm{MgK} \alpha, \mathrm{FeK} \alpha$ emissions of dolomite. Scanning speed was $10 \mu \mathrm{m}$ per minute. Sample 364-35-2, 46-48 cm. sediments deposited in reducing conditions containing organic matter and pyrite (Davies and Supko, 1973). Elsewhere, a Cenomanian pyrite-bearing sequence of alternating dolomitic silts and sapropelites was cored at Site 138 at about 425 meters subbottom (Hayes and Pimm, 1972). Dolomite in the late Miocene to Pliocene Red Sea sediments recovered during Leg 23 has characteristic occurrences and displacement of $d_{104}$ spacing similar to those of types A and B dolomite in this work (Supko et al., 1974). The dolomite in the Leg 23 sediments, accompanied by abundant organic materials, shows the same displacement of $d_{104}$ spacing as type B high-iron dolomite in this work. On the other hand, dolomite which occurs associated with evaporites, has the $d_{104}$ spacing close to that of type A low-iron dolomite in this work. There is a possibility that displacements of $d_{104}$ of Red Sea dolomite was caused not only by the substitution of $\mathrm{Mg}$ by $\mathrm{Ca}$, but also $\mathrm{Mg}$ by $\mathrm{Fe}$, as shown in this work.

\section{ACKNOWLEDGMENTS}

The authors wish to express appreciation to Professor Azuma Iijima, Geological Institute, the University of Tokyo, for reading the manuscript and to Professor Noriyuki Nasu, Ocean Research Institute, the University of Tokyo, who arranged for the work.

\section{REFERENCES}

Albee, A.L. and Ray, L., 1970. Correction factors for electron probe microanalysis of silicates, oxides, carbonates, phosphates, and sulfates: Anal. Chem., v. 42, p. 14081414.

Bence, A.E. and Albee, A.L., 1968. Empirical correction factors for the electron microprobe analysis of silicates and oxides: J. Geol., v. 76, p. 382-403. 
TABLE 1

Chemical Analysis of Dolomite and Ankerite of Sites 363 and 364

\begin{tabular}{|c|c|c|c|c|c|c|c|c|c|c|c|c|c|}
\hline & $1^{\mathrm{a}}$ & $2^{\mathrm{a}, \mathrm{b}}$ & $3^{c}$ & $4^{a, b}$ & $5^{\mathrm{c}}$ & $6^{\mathrm{c}}$ & $7^{\mathrm{c}}$ & $8^{\mathrm{c}}$ & $9^{a}$ & $10^{\mathrm{c}}$ & $11^{\mathrm{a}}$ & $12^{\mathrm{a}}$ & $13^{c}$ \\
\hline $\mathrm{MgO}$ & 15.43 & 14.83 & 16.75 & 14.26 & 17.19 & 15.69 & 18.92 & 17.14 & 15.51 & 18.31 & 16.01 & 17.52 & 17.57 \\
\hline $\mathrm{CaO}$ & 32.52 & 31.69 & 33.83 & 31.00 & 33.13 & 32.47 & 32.43 & 32.93 & 32.43 & 24.22 & 33.39 & 32.68 & 34.32 \\
\hline $\mathrm{FeO}$ & 5.22 & 6.45 & 2.26 & 8.25 & 3.54 & 5.88 & 0.80 & 2.16 & 5.29 & 0.20 & 4.09 & 2.99 & 0.32 \\
\hline $\mathrm{MnO}$ & 0.20 & 0.24 & 0.07 & 0.11 & 0.18 & 0.20 & 0.03 & 0.24 & 0.24 & 0.05 & 0.05 & 0.03 & 0.06 \\
\hline $\mathrm{Na}_{2} \mathrm{O}$ & 0.07 & 0.00 & 0.00 & 0.06 & 0.00 & 0.01 & 0.03 & 0.22 & 0.00 & 0.05 & 0.05 & 0.03 & 0.02 \\
\hline $\mathrm{CO}_{2}$ & 45.52 & 45.15 & 46.07 & 44.87 & 47.07 & 46.34 & 46.73 & 45.99 & 45.76 & 46.86 & 46.11 & 46.50 & 46.17 \\
\hline Total & 98.96 & 98.36 & 98.98 & 98.55 & 101.08 & 100.60 & 99.39 & 98.68 & 99.23 & 99.72 & 99.79 & 99.83 & 98.46 \\
\hline
\end{tabular}

Molecular Percent

\begin{tabular}{|c|c|c|c|c|c|c|c|c|c|c|c|c|c|}
\hline $\mathrm{MgCO}_{3}$ & 36.86 & 35.85 & 39.58 & 34.59 & 39.89 & 36.96 & 44.07 & 40.56 & 37.00 & 42.54 & 37.79 & 41.01 & 41.42 \\
\hline $\mathrm{CaCO}_{3}$ & 55.77 & 55.07 & 57.57 & 53.95 & 55.27 & 54.98 & 54.20 & 55.91 & 55.60 & 57.07 & 56.55 & 54.88 & 58.05 \\
\hline $\mathrm{FeCO}_{3}$ & 6.99 & 8.75 & 2.99 & 11.22 & 4.61 & 7.76 & 1.05 & 2.87 & 7.08 & 0.26 & 5.41 & 3.92 & 0.42 \\
\hline $\mathrm{MnCO}_{3}$ & 0.27 & 0.33 & 0.09 & 0.15 & 0.23 & 0.27 & 0.64 & 0.32 & 0.33 & 0.11 & 0.19 & 0.15 & 0.08 \\
\hline $\mathrm{Na}_{2} \mathrm{CO}_{3}$ & 0.11 & 0.00 & 0.00 & 0.09 & 0.00 & 0.02 & 0.05 & 0.34 & 0.00 & 0.08 & 0.08 & 0.05 & 0.03 \\
\hline Total & 100.00 & 100.00 & 100.01 & 100.00 & 100.00 & 99.99 & 100.01 & 100.00 & 100.01 & 100.00 & 100.02 & 100.01 & 100.00 \\
\hline
\end{tabular}

\begin{tabular}{|c|c|c|c|c|c|c|c|c|c|c|c|c|c|}
\hline & $14^{a, b}$ & $15^{\mathrm{c}}$ & $16^{\mathrm{a}, \mathrm{b}}$ & $17^{\mathrm{c}}$ & $18^{\mathrm{a}}$ & $19^{\mathrm{c}}$ & $20^{\mathrm{c}}$ & $21^{\mathrm{a}, \mathrm{b}}$ & $22^{\mathrm{c}}$ & $23^{a, b}$ & $24^{\mathrm{c}}$ & $25^{\mathrm{c}}$ & $26^{a, b}$ \\
\hline $\mathrm{MgO}$ & 14.46 & 17.77 & 13.50 & 16.84 & 14.33 & 16.82 & 18.42 & 14.21 & 18.11 & 14.84 & 16.52 & 16.70 & 15.39 \\
\hline $\mathrm{CaO}$ & 32.87 & 33.76 & 33.20 & 34.06 & 33.30 & 34.89 & 34.38 & 34.14 & 34.98 & 31.62 & 32.77 & 32.17 & 31.89 \\
\hline $\mathrm{FeO}$ & 6.66 & 2.35 & 7.45 & 2.07 & 5.44 & 0.02 & 0.17 & 6.12 & 0.14 & 6.55 & 4.03 & 3.56 & 6.68 \\
\hline $\mathrm{MnO}$ & 0.33 & 0.28 & 0.33 & 0.23 & 0.15 & 0.20 & 0.20 & 0.24 & 0.20 & 0.03 & 0.48 & 0.10 & 0.10 \\
\hline $\mathrm{Na}_{2} \mathrm{O}$ & 0.00 & 0.13 & 0.03 & 0.00 & 0.00 & 0.02 & 0.00 & 0.00 & 0.00 & 0.00 & 0.05 & 0.00 & 0.03 \\
\hline $\mathrm{CO}_{2}^{2}$ & 45.86 & 47.58 & 45.57 & 46.52 & 45.19 & 45.88 & 47.11 & 46.20 & 47.42 & 44.86 & 46.55 & 45.52 & 45.99 \\
\hline Total & 100.20 & 101.86 & 100.09 & 99.72 & 98.41 & 97.82 & 100.28 & 100.91 & 100.85 & 97.90 & 100.40 & 98.05 & 100.08 \\
\hline
\end{tabular}

\section{Molecular Percent}

\begin{tabular}{|c|c|c|c|c|c|c|c|c|c|c|c|c|c|}
\hline $\mathrm{MgCO}_{3}$ & 34.42 & 40.76 & 32.33 & 39.52 & 34.60 & 40.01 & 42.54 & 33.59 & 41.68 & 36.01 & 38.73 & 39.92 & 36.53 \\
\hline $\mathrm{CaCO}_{3}$ & 56.23 & 55.66 & 57.16 & 57.45 & 57.82 & 59.66 & 56.98 & 57.98 & 57.88 & 55.04 & 55.24 & 55.17 & 54.40 \\
\hline $\mathrm{FeCO}_{3}$ & 8.90 & 3.02 & 10.01 & 2.73 & 7.37 & 0.03 & 0.21 & 8.12 & 0.18 & 8.92 & 5.30 & 4.77 & 8.90 \\
\hline $\mathrm{MnCO}_{3}$ & 0.45 & 0.36 & 0.45 & 0.31 & 0.21 & 0.27 & 0.26 & 0.32 & 0.26 & 0.04 & 0.64 & 0.14 & 0.13 \\
\hline $\mathrm{Na}_{2} \mathrm{CO}_{3}$ & 0.00 & 0.19 & 0.04 & 0.00 & 0.00 & 0.03 & 0.00 & 0.00 & 0.00 & 0.00 & 0.08 & 9.00 & 0.04 \\
\hline Total & 100.00 & 99.99 & 99.99 & 100.01 & 100.00 & 100.00 & 100.00 & 100.00 & 100.01 & 100.01 & 99.99 & 100.00 & 100.01 \\
\hline
\end{tabular}

\begin{tabular}{lrrrrrrrrrrr} 
& \multicolumn{1}{c}{$27^{\mathrm{a}}$} & \multicolumn{1}{c}{$28^{\mathrm{a}}$} & \multicolumn{1}{c}{$29^{\mathrm{a}}$} & \multicolumn{1}{c}{$30^{\mathrm{c}}$} & \multicolumn{1}{c}{$31^{\mathrm{c}}$} & \multicolumn{1}{c}{$32^{\mathrm{a}}$} & $33^{\mathrm{a}}$ & $34^{\mathrm{c}}$ & $35^{\mathrm{a}}$ & $36^{\mathrm{c}}$ & $37^{\mathrm{c}}$ \\
$\mathrm{MgO}$ & 13.32 & 18.80 & 18.97 & 19.32 & 19.86 & 18.91 & 19.50 & 20.51 & 19.29 & 20.94 & 20.60 \\
$\mathrm{CaO}$ & 33.25 & 33.89 & 33.14 & 33.33 & 32.63 & 32.75 & 31.95 & 30.61 & 32.31 & 32.23 & 32.64 \\
$\mathrm{FeO}$ & 0.17 & 0.04 & 0.01 & 0.08 & 0.08 & 0.05 & 0.03 & 0.14 & 0.05 & 0.20 & 0.14 \\
$\mathrm{MnO}$ & 0.20 & 0.19 & 0.22 & 0.21 & 0.19 & 0.15 & 0.16 & 0.15 & 0.27 & 0.16 & 0.11 \\
$\mathrm{Na}{ }_{2} \mathrm{O}$ & 0.10 & 0.10 & 0.06 & 0.05 & 0.14 & 0.08 & 0.07 & 0.07 & 0.06 & 0.08 & 0.08 \\
$\mathrm{CO}_{2}$ & 47.78 & 46.90 & 46.90 & 47.45 & 47.54 & 46.59 & 46.35 & 46.46 & 46.50 & 48.43 & 48.31 \\
Total & 100.52 & 100.33 & 99.31 & 100.43 & 100.43 & 98.55 & 98.06 & 97.97 & 98.45 & 102.05 & 101.88
\end{tabular}

\begin{tabular}{lrrrrrrrrrrr}
\multicolumn{2}{l}{ Molecular Percent } \\
$\mathrm{MgCO}_{3}$ & 44.43 & 43.37 & 44.15 & 44.44 & 45.59 & 44.38 & 45.80 & 48.06 & 45.18 & 47.20 & 46.55 \\
$\mathrm{CaCO}_{3}$ & 54.95 & 56.18 & 55.44 & 55.11 & 53.85 & 55.24 & 53.84 & 51.46 & 54.30 & 52.22 & 53.01 \\
$\mathrm{FeCO}_{3}$ & 0.22 & 0.05 & 0.02 & 0.10 & 0.10 & 0.07 & 0.04 & 0.18 & 0.07 & 0.25 & 0.18 \\
$\mathrm{MnCO}_{3}$ & 0.26 & 0.25 & 0.29 & 0.28 & 0.25 & 0.20 & 0.21 & 0.20 & 0.30 & 0.21 & 0.14 \\
$\mathrm{Na}_{2} \mathrm{CO}_{3}$ & 0.15 & 0.15 & 0.09 & 0.07 & 0.21 & 0.12 & 0.11 & 0.11 & 0.09 & 0.12 & 0.12 \\
Total & 100.01 & 100.00 & 99.99 & 100.00 & 100.00 & 100.01 & 100.00 & 100.01 & 100.00 & 100.00 & 100.00
\end{tabular}

Note: Data in columns are as follows; 1,2 , and 3-Sample 363-32-5, 36-38 cm;4, 5, and 6-Sample 363-34-3, 36-38 cm; 7, 8, and 9-Sample $363-37-1,58-60 \mathrm{~cm} ; 10,11,12$, and $13-$ Sample $363-38, \mathrm{CC} ; 14,15$, and $16-$ Sample $364-35-2,46-48 \mathrm{~cm} ; 17,18,19$, and $20-$ Sample $364-$ $38-4,139-140 \mathrm{~cm} ; 21$ and $22-$ Sample $364-38-5,41-42 \mathrm{~cm} ; 23,24,25$, and 26 -Sample $364-41-4,135-137 \mathrm{~cm} ; 27,28,29,30$, and 31-Sample $364-44-3,2-3 \mathrm{~cm} ; 32,33,34$, and $35-$ Sample $364-45-3,26-28 \mathrm{~cm} ; 36$ and $37-$ Sample $364-46-1,109-110 \mathrm{~cm}$.

${ }^{\mathrm{a}} \mathrm{Rim}$ of dolomite and ankerite crystals.

b Ankerite.

${ }^{\mathrm{c}}$ Core of dolomite crystal. 


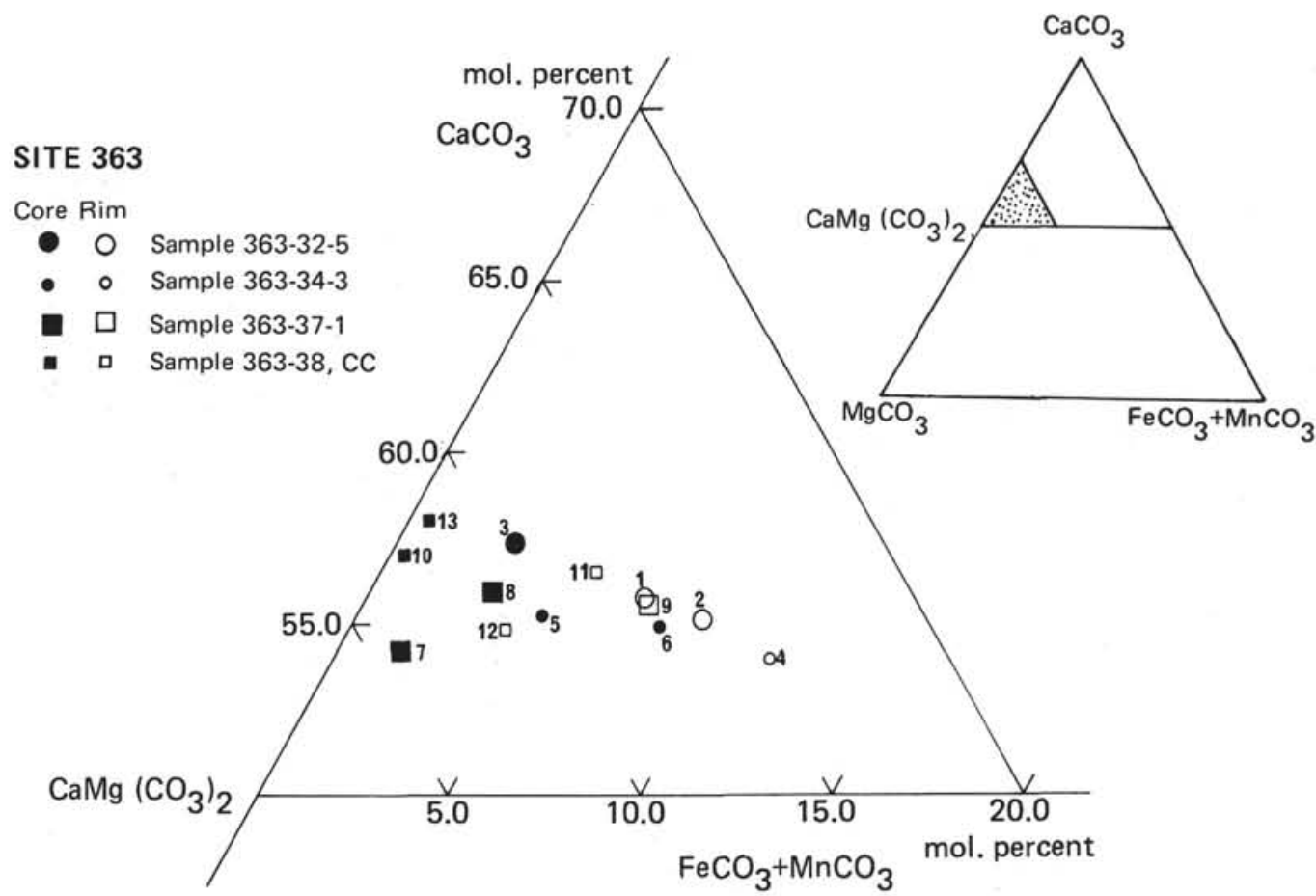

Figure 12. Chemical composition of dolomite at Site 363 plotted in the system $\mathrm{CaCO}_{3}-\mathrm{MgCO}_{3}$

$$
-\mathrm{FeCO}_{3}+\mathrm{MnCO}_{3}
$$

TABLE 2

Comparison Between Observed and Calculated Composition of Dolomite

\begin{tabular}{|c|c|c|c|c|c|c|c|c|}
\hline \multirow[b]{3}{*}{ Section } & \multicolumn{4}{|c|}{ Present Work } & \multicolumn{4}{|c|}{ Previous Method } \\
\hline & \multicolumn{3}{|c|}{$\begin{array}{c}\text { Observed Chemical } \\
\text { Compositions with X-Ray } \\
\text { Microanalyzer (mol \%) }\end{array}$} & \multirow{2}{*}{$\begin{array}{c}\text { Calculated } \\
d_{104} \underset{(\AA)}{\text { Spacing }}\end{array}$} & \multirow{2}{*}{$\begin{array}{c}\text { Observed Values } \\
\text { of } d_{104} \text { Spacing } \\
\text { with X-Ray } \\
\text { Diffraction } \\
\text { Analyzer }(\AA)\end{array}$} & \multicolumn{3}{|c|}{$\begin{array}{l}\text { Calculated Chemical } \\
\text { Compositions (mol \%) }\end{array}$} \\
\hline & $\mathrm{CaCO}_{3}$ & $\mathrm{MgCO}_{3}$ & $\mathrm{FeCO}_{3}$ & & & $\mathrm{CaCO}_{3}$ & $\mathrm{MgCO}_{3}$ & $\mathrm{FeCO}_{3}$ \\
\hline $363-32-5$ & $55-67$ & $36-40$ & 3-9 & $2.907-2.909$ & 2.907 & 58 & 42 & - \\
\hline $363-34-3$ & $54-55$ & $35-40$ & $5-11$ & $2.905-2.907$ & 2.907 & 58 & 42 & - \\
\hline $363-37-1$ & $54-56$ & $37-44$ & $2-6$ & $2.900-2.908$ & 2.906 & 57 & 43 & - \\
\hline $364-35-2$ & $56-57$ & $32-41$ & $3-10$ & $2.905-2.915$ & 2.911 & 59 & 41 & - \\
\hline $364-38-4$ & $57-60$ & $35-42$ & $0-8$ & $2.906-2.915$ & 2.908 & 58 & 42 & - \\
\hline $364-41-4$ & $54-55$ & $36-40$ & $5-9$ & $2.905-2.908$ & 2.908 & 55 & 45 & - \\
\hline $364-44-3$ & $52-55$ & $45-58$ & 0.5 & $2.897-2.903$ & 2.899 & 55 & 45 & - \\
\hline $364-46-1$ & $52-53$ & 47 & 0.5 & $2.892-2.895$ & 2.896 & 53 & 47 & - \\
\hline
\end{tabular}

TABLE 3

Types of Dolomite Found in Leg 40

\begin{tabular}{llll}
\hline Type & Site and Unit & \multicolumn{1}{c}{ Lithology } & Mineralogy \\
\hline A & $364-5$ & $\begin{array}{l}\text { Argillaceous dolostone } \\
\text { with small amounts of } \\
\text { pyrite and gypsum }\end{array}$ & $\begin{array}{l}\text { Dolomite and } \\
\text { calcian dolomite }\end{array}$ \\
B & $364-4,363-2$ & $\begin{array}{l}\text { Dolomitic limestone } \\
\text { with carbonaceous shale }\end{array}$ & $\begin{array}{l}\text { Ferro-calcian } \\
\text { dolomite and } \\
\text { calcian ankerite }\end{array}$ \\
\hline
\end{tabular}

Davies, T.A. and Supko, P.R., 1973. Oceanic sediments and their diagenesis: Some examples from deep-sea drilling: J. Sediment. Petrol., v. 43, p. 381-390.

Deer, W.A., Howie, R.A., and Zussman, J., 1963. Rock forming minerals, v. 5: London (Longmans, Green and Co. Ltd.), p. 371 .
Fritz, P. and Katz, A., 1972. The sodium distribution of dolomite crystals: Chem. Geol., v. 10, p. 237-244.

Goldsmith, J.R. and Graf, D.L., 1958a. Relation between lattice constants and composition of the $\mathrm{Ca}-\mathrm{Mg}$ carbonates: Am. Mineral., v. 43, p. 84-101. 1958 b. Structural and compositional variations in some natural dolomites: J. Geol., v. 66, p. 678-693.

Goldsmith, J.R., Graf, D.L., Witters, J., and Northrop, D.A., 1962. Studies in the system $\mathrm{CaCO}_{3}-\mathrm{MgCO}_{3}-\mathrm{FeCO}_{3}: 1$. phase relations; 2 . a method for major-element spectrochemical analysis; 3 . compositions of some ferroan dolomites: J. Geol., v. 70, p. 659-688.

Hayes, D.E., Pimm, A.C., et al., 1972. Initial Reports of the Deep Sea Drilling Project, Volume 14: Washington (U.S. Government Printing Office).

Krumbine, W.C. and Garrels, R.M., 1952. Origin and classification of chemical sediments in terms of $p \mathrm{H}$ and oxidation-reduction potentials: J. Geol., v. 60, p. 1-33. 


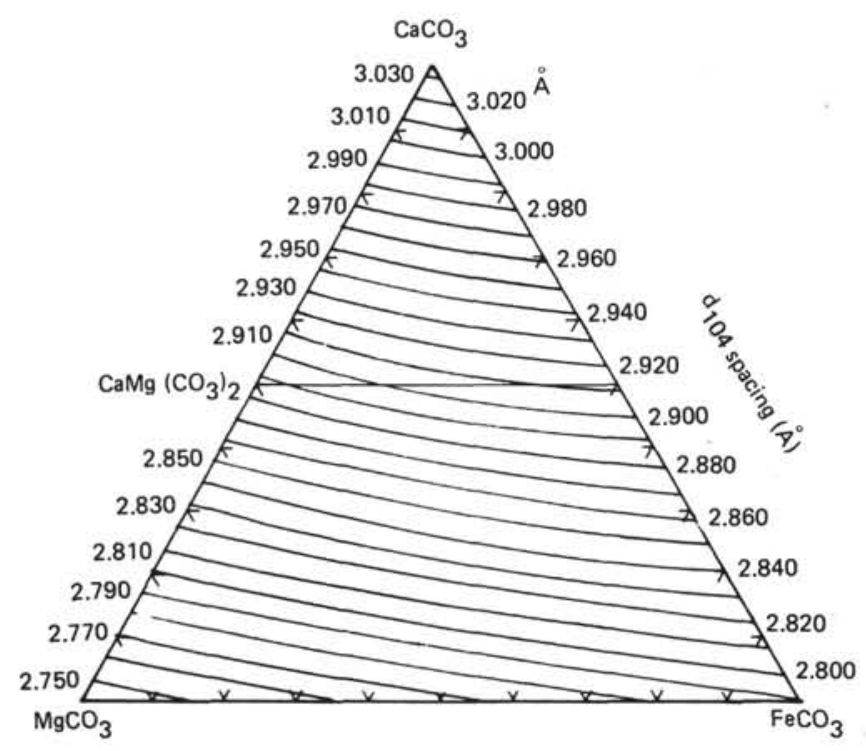

Figure 13. Variation in the value of $d_{104}$ spacing $(A)$ of carbonates with composition (mol \%) in the system $\mathrm{CaCO}_{3}-\mathrm{MgCO}_{3}-\mathrm{FeCO}_{3}$. The graph is prepared from the present study with supplemental data after Goldsmith and Graf (1958), Goldsmith et al. (1962), and Rosenberg $(1963,1967)$.

Land, L.S. and Hoops, G.K., 1973. Sodium in carbonate sediments and rocks: A possible index to the salinity of diagenetic solutions: J. Sediment. Petrol., v. 43, p. 614617.

Matsumoto, R. and Iijima, A., 1975. Geochemistry of carbonates in Japanese Paleogene coal measures: 9th Intern. Cong. Sedimentol. Proc., Nice 1975, Theme 2.
Melguen, M. et al., 1975. Facies evolution and carbonate dissolution cycles in sediments from basins and continental margins of the eastern South Atlantic since early Cretaceous: 9 th Inter. Cong. Sedimentol. Proc., Nice 1975.

Oinuma, 1. and Kobayashi, K., 1961a. Clay mineralogical study on the sedimentary rocks of the Kamisunagawa district, Ishikari coal field, Hokkaido (II): Geol. Mag., v. 66, p. $506-516$.

1961b. Problems of rapid clay mineralogical analysis of sedimentary rocks: Clay Sci., v. 1, p. 8-15.

Perry, G.A., Jr., Gieskes, J.M., and Lawrence, J.R., 1976. $\mathrm{Mg}, \mathrm{Ca}$, and $\mathrm{O}^{18} / \mathrm{O}^{16}$ exchange in the sediment-pore water system, Hole 149, DSDP: Geochim. Cosmochim. Acta, v. 40, p. $413-423$.

Raiswell, R., 1971. The growth of Cambrian and Liassic concretions: Sedimentology, v. 17, p. 147-171.

Rosenberg, P.E., 1963. Subsolidus relations in the system $\mathrm{CaCO}_{3}-\mathrm{FeCO}_{3}: \mathrm{Am}$. Jr. Sci., v. 261, p. 683-690.

1967. Subsolidus relations in the system $\mathrm{CaCO}_{3}-$ $\mathrm{MgCO}_{3}-\mathrm{FeCO}_{3}$ between $350^{\circ}$ and $550^{\circ} \mathrm{C}$ : Am. Mineral., v. 25 , p. $787-796$.

Supko, P.R., Stoffers, P., and Coplen, T.B., 1974. Petrography and geochemistry of Red Sea dolomite. In Whitmarsh, R.B., Weser, O.E., Ross, D.A., et al., Initial Reports of Deep Sea Drilling Project, Volume 23: Washington (U.S. Government Printing Office), p. 867878.

Taylor, R.K. and Spears, D.A., 1967. Unusual carbonate band in the east Pennine coal field (England): Sedimentology, v. 9, p. 55-73.

Wada, K. and Yamada, H., 1968. Hydrazine intercalationintersaltation for differentiation of Kaolin minerals from chlorites: Am. Mineral., v. 53, p. 334-339. 